\title{
Pengaruh Senam Kaki terhadap Nilai Ankle Brachial Index Pada Pasien Diebetes Melitus Tipe II: Sebuah Tinjauan Sistematis
}

\author{
Yofa Anggriani Utama*, Sutrisari Sabrina Nainggolan \\ Dosen Keperawatan, Sekolah Tinggi Ilmu Kesehatan Bina Husada \\ *Correspondence email: yofaanggriani@yahoo.co.id, sutrisarisabrinanainggolan@gmail.com
}

\begin{abstract}
Abstrak. Diabetes mellitus merupakan penyakit kronis yang terjadi akibat gangguan metabolik yang ditandai dengan kadar gula darah yang melebihi batas normal. Kaki diabetik merupakan salah satu komplikasi diabetes mellitus yang dapat menyebabkan terjadinya ulkus, infeksi, gangren dan atropati charcot.Senam kaki diabetik merupakan salah satu intervensi yang dapat mengatasi masalah sirkulasi perifer yang terjadi pada pasien diabetes mellitus tipe 2. Adapun tujuan penelitian ini adalah diidentifikasinya pengaruh senam kaki diabetik terhadap nilai ankle brachial index pada pasien Diabetes Melitus Type II melalui sistematik review. Adapun desain penelitian yang masuk dalam sistematik review ini menggunakan desain penelitian yaitu metode kuantitatif dengan pendekatan sistematik review. Artikel pertama menunjukkan bahwa pada kelompok perlakuan mengalami peningkatan mean dan pada kelompok kontrol mengalami penurunan mean. Aktifitas fisik responden mempengaruhi dari nilai ABI sesaat sebelum dilakukan pemeriksaan ABI, dan juga dipengaruhi oleh kolesterol yang mana peneliti tidak melakukan pengontrolan pada semua responden.Sehingga dapat disimpulkan bahwa intervensi senam kaki diabetes berpengaruh dalam meningkatkan sirkulasi darah ke kaki.Artikel kedua menunjukkan bahwa apabila dibandingkan hasil nilai ABI untuk kedua kelompok maka terdapat hasil yang signifikan, sehingga senam kaki diabetik dapat diberikan sebanyak empat kali seminggu selama satu bulan, memberikan manfaat yang baik dalam meningkatkan tekanan darah di kaki.Hasil tinjauan sistematik ini menunjukkan bahwa senam kaki memberikan pengaruh yang baik terhadap ankle brachial index pada pasien diabetes mellitus tipe 2 yang mengalami masalah pada perfusi perifer. Apabila intervensi ini diberikan sesering mungkin maka akan memberikan pengaruh yang baik terhadap rentang gerak sendi sehingga dapat meningkatkan kualitas hidup pasien diabetes mellitus tipe 2 .
\end{abstract}

Kata kunci: senam kaki; Ankle Brachial Index; Pasien Diebetes Melitus

\begin{abstract}
Diabetes mellitus is a chronic disease that occurs due to metabolic disorders characterized by blood sugar levels that exceed normal limits. Diabetic foot is a complication of diabetes mellitus that can cause ulcers, infection, gangrene and charcot's atrophy. Diabetic foot exercise is one of the interventions that can overcome peripheral circulation problems that occur in type 2 diabetes mellitus patients.The purpose of this study is to identify the effect of diabetic foot exercise on the value of the ankle brachial index in Type II Diabetes Mellitus patients through a systematic review. The research design included in this systematic review uses a research design that is a quantitative method with a systematic review approach. The first article shows that the treatment group experienced an increase in mean and the control group experienced a decrease in the mean. The physical activity of the respondents affected the ABI value just before the ABI examination was carried out, and it was also influenced by cholesterol which the researchers did not control for all respondents. So it can be concluded that the diabetes foot exercise intervention has an effect in increasing blood circulation to the feet. The second article shows that when compared to the results of the ABI values for the two groups there are significant results, so that diabetic foot exercises can be given four times a week for one month, providing good benefits in increasing blood pressure in the legs. The results of this systematic review indicate that foot exercise has a good effect on ankle brachial index in type 2 diabetes mellitus patients who have problems with peripheral perfusion. If this intervention is given as often as possible, it will have a good effect on the range of motion of the joints so that it can improve the quality of life of patients with type 2 diabetes mellitus.
\end{abstract}

Keywords: foot gymnastics; Ankle Brachial Index; Diebetes Melitus Patients

\section{PENDAHULUAN}

Diabetes melitus diklasifikasikan 4 kategori yaitu: Diabetes melitus tipe 1 akibat kerusakan sel B defisiensi insulin; diabetes melitus tipe 2 akibat hilangnya sekresi insulin; diabetes melitus gestasional terdiagnosa pada trimeseter ke dua atau ketiga kehamilan; jenis diabetes tertentu akibat penyakit lain misalnya sindrom diabetes monogenik (American Diabetes Association, 2020). Prevalensi Diabetes Melitus pada tahun 2018 berdasarkan diagnosa dokter, jenis kelamin, dan daerah domisili. Berdasarkan kategori usia, penderita berada pada rentang usia 55-64 tahun dan 65-74 tahun. Selain itu penderita diabetes mellitus di Indonesia lebih banyak berjenis kelamin perempuan $(1,8 \%)$ dari pada lakilaki(1,2\%). Kemudian untuk daerah domisili lebih banyak penderita diabetes mellitus yang berada di perkotaan $(1,9 \%)$ dibandingkan di pedesaan (INFODATIN RI, 2018).

Kaki diabetes merupakan salah satu komplikasi penyakit diabetes melitus yang paling sering terjadi, karena gangguan patologi seperti terjadinya infeksi, ulkus dan amputasi. Untuk mengatasi hal tersebut dilakukan aktivitas fisik seperti olahraga atau senam kaki dibates dapat meningkatkan peredaran darah perifer dan memperbaiki fungsi saraf (Matos, Mendes, Silva, \& Sousa, 2018). 
Penyakit Peripheral artery disease (PAD) serta gejala kaki diabetes dapat diatas dengan aktivitas fisik seperti olahraga, salah satu olahraga yang dapat dilakukan kan yaitu treadmil karena dapat meningkatkan kinerja berjalan pada penderita Peripheral artery disease (PAD) (Mcdermott, 2017).

Ulkus kaki diabetik merupakan salah satu komplikasi yang sangat serius dari penyakit diabetes melitus untuk mencegah dan mengatasi terjadinya ulkus kaki diabetik yang disebabkan oleh perifer neuropati dan penyakit arteri periper dengan mengukur nilai Ankle Brachial Index dengan menggunakan doppler serta menilai kadar glukosa darah (Lung et al., 2020).

Senam kaki dapat meningkatkan ankle brachial index pada pasien diabetes mellitus. Ada perbedaan mean ankle brachial index yang bermakna antara kelompok perlakuan yang diberikan intervensi senam kaki dan kelompok kontrol yang tidak diberikan senam kaki, dimana mean ankle brachial index dengan senam kaki lebih tinggi kaki daripada yang tidak diberikan senam kaki. Latihan fisik sepeti senam kaki akan memperbaiki sirkulasi darah sehingga meningkatkan aliran darah kaki dan meningkatkan tekanan darah sistolik pada kaki (Ivo Tomy Pompang'k Toton, 2016)

Penelitian yang dilakukan oleh Mangiwa, Katuuk, \& Sumarauw, 2017), sebagian besar pasien DM tipe II berumur 51-60 tahun, berjenis kelamin perempuan, lama diabetes mellitus kurang sama dengan 5 tahun, dan tidak ada riwayat merokok. Sebelum dilakukan atau diberikan senam kaki diabetes, sebagian besar pasien DM tipe II mempunyai nilai Ankle Brachial Index gangguan arterial ringan.Setelah dilakukan atau diberikan senam kaki diabetes, nilai Ankle Brachial Index mengalami perubahan yang cukup signifikan dengan meningkatnya nilai Ankle Brachial Index menjadi normal.Hal ini menunjukkan terdapat pengaruh yang signifikan terhadap nilai Ankle Brachial Index sebelum dan sesudah diberikan senam kaki diabetes.

Senam kaki diabetik memberikanstimulasi pada otot gastroknemius, kontraksi yang efektif pada otot-otot betis (gastrocnemius dan soleus) dapat meningkatkan kekuatan otot betis dan pompa otot betis (calf pumping) yang akan menfasilitasi venous return dan dapat memperbaiki sirkulasi pembuluh darah vena. Latihan fisik telah terbukti dapat meningkatkan efisiensi pompa otot betis sehingga meningkatkan tekanan darah kaki yang berdampak pada nilai ABI.Hasil penelitian tersebut mendapatkan latihan senam kaki diabetik dapat meningkatkan ankle brachial index (ABI) pada pasien diabetes melitus tipe II sehingga mengurangi kemungkinan terjadinya komplikasi makrovskuler seperti luka kaki diabetes dan menghindarkan tindakan amputasi (Ni Putu Erna Libya, 2018).

Penerapan senam diabetes sebagai salah satu aktivitas penderita dalam penurunan kadar gula darah. Apabila rutin melakukan latihan fisik dan senam diabetes pada pasien diabetes, yang mengalami gangguan vaskularisasi, maka akan terjadi perubahan nilai ABI yang bermakna dan mencegah terjadinya gangguan pada tungkai kaki bagian bawah. Hal ini terbukti pada penderita diabetes di Puskesmas Simpang IV Sipin Kota Jambi yang rutin melakukan senam diabetes satu kali/minggu dimana nilai Ankle Brachial Index berada di rentang normal di antara nilai 0,90-1,30 dan penelitian yang dilakukan tiga kali/minggu terjadi kenaikan nilai Ankle Brachial Index dari nilai 1,05 mejadi 1,20 selama 3 minggu dilakukan (Kaimuddin \& Selamat, 2019).

Kaki diabetes merupakan salah satu infeksi kronik DM yang paling ditakuti, dan berakhir dengan kecacatan dan kematian. Salah satu pencegahan yang dapat dilakukan adalah melakukan senam kaki dimana akan membantu sirkulasi darah pada daerah kaki. Rata-rata nilai ABI penderita DM tipe II sebelum dilakukan senam kaki pada nilai 0,88 , dan setelah dilakukan senam kaki pada nilai 0,97 . Terjadi kenaikan nilai ABI sebanyak 0,09 antara ABI sebelum dan ABI sesudah dilakukan senam kaki. Hal ini menunjukkan adanya pengaruh senam kaki diabetes terhadap nilai ankle brachial index pada pasien DM tipe II (nilai $\mathrm{p}=0,001$ ). Sehingga senam kaki diabetes merupakan salah satu prinsip dalam penatalaksanaan penyakit diabetes mellitus dengan pendekatan non farmakologi dalam mengatasi terjadinya amputasi (Tut Wuri Prihatin, 2019)

Senam kaki diabetes mempengaruhi nilai ABI, dimana senam kaki dapat meningkatkan sirkulasi darah kaki.Latihan fisik ini merupakan salah satu prinsip dalam penatalaksanaan penyakit DM, dimana latihan fisik yang dilakukan secara regular juga termasuk ke dalam pencegahan sekunder faktor resiko komplikasi diabetes terutama terjadinya kaki diabetek dan amputasi (Megawati, Utami, \& Jundiah, 2020)

Ankle Brachial Index (ABI) pada pasien diabetes sebelum dilakukan intervensi senam kaki didapati berada pada kategori gangguan ulkus vena dan gangguan ulkus arterivena. Hal ini dipengaruhi usia responden yang lebih dari 50 tahun, penggunaan obat gula dan mayoritas berjenis kelamin laki-laki. ABI sesudah intervensi senam kaki didapati berada pada kategori gangguan vena persentasenya menurun, sedangkan kategori vena normal persentasenya meningkat.Perbandingan sebelum dan sesudah intervensi didapati pengaruh yang signifikan terhadap perubahan nilai ABI pada ekstremitas bawah (Simarmata, Sri, Purba, \& Lestari, 2021).

Penelitian tentang pengaruh senam kaki diabetes terhadap nilai ankle brachial index pada pasien diabetes mellitus telah banyak dilaporkan pada beberapa desain penelitian quasi experiment.Oleh sebab itu, penulis tertarik untuk menyusun sebuah tinjauan sistematis mengenai hal tersebut.

\section{METODE}

Penelitian ini merupakan systematic review. Sumber data penelitian ini berasal dari literatur yang 
diperoleh dari pencarian utama melalui SINTA (sinta.ristekbrin.go.id) dan sumber pencarian lain melalui Portal Garuda (garuda.ristekbrin.go.id) serta google scholar (sholar.google.com). Untuk mendapatkan artikel internasional, pencarian melalui science direct (sciencedirect.com) dan pubmed (pubmed.ncbi.nlm.nih.gov). Kriteria inklusi artikel yang digunakan adalah pasien diabetes mellitus tipe 2 , senam kaki diabetes, hasil pengaruh senam kaki diabetes terhadap nilai ankle brachial index, Quasy experimental; one group pre-post test with control design. Hasil pencarian didapatkan sebanyak 543 artikel. Artikel yang sesuai dengan kata kunci, dengan rincian basis data dari Google Scholar didapatkan 176 artikel, dari basis data Portal Garuda didapatkan 6 artikel, dari basis data Sinta didapatkan 1 artikel, dan dari basis data Science Direct didapatkan 360 artikel. Selanjutnya dilakukan skrining berdasarkan duplikasi didapatkan 216 artikel, kemudian artikel tersebut diskrining berdasarkan kesesuaian dengan judul/topik penelitian tersisa 16 artikel, berikutnya artikel tersebut dilakukan skrining berdasarkan kriteria inklusi dan kriteria seleksi studi sehingga tersisa 2 artikel.

\section{HASIL DAN PEMBAHASAN}

Berdasarkan hasil pencarian didapatkan sebanyak 543 artikel yang dianggap sesuai dengan tujuan penelitian kemudian dijadikan satu lalu dilakukan screening apakah judul pada artikel tersebut ada yang sama atau tidak. Setelah dilakukan screening didapatkan ada 216 artikel yang judulnya sama, dari 2 artikel ini kemudian di screening berdasarkan eligibility sesuai dengan kriteria inklusi dan eksklusi didapatkan 2 artikel untuk selanjutnya dilakukan review. Adapun strategi pencarian literature tadi dapat dilihat pada table 1 .

Tabel 1. Strategi pencarian literature

\begin{tabular}{|c|c|c|c|c|}
\hline Mesin Pencari & Google Scholar & Portal Garuda & Sinta & Science Direct \\
\hline Hasil penelusuran & 176 & 6 & 1 & 360 \\
\hline Artikel setelah dihilangkan duplikasi & 108 & & 1 & 107 \\
\hline Artikel setelah disaring berdasarkan judul/topik & 16 & & & \\
\hline Artikel full text yang disaring berdasarkan kriteria inklusi & 2 & & & \\
\hline Result & 2 & & & \\
\hline
\end{tabular}

Penelitian yang layak terdiri dari beberapa studi yang dilakukan.Analisa dari 2 artikel itu menunjukkan bahwa jurnal dengan desai Quasy experimental; one group pre-post test with control design.Setelah dilakukan pengkajian kualitas studi dari 2 artikel ini sesuai dengan kriterianya sehingga dilakukan ekstraksi data. Ekstraksi data ini dilakukan dengan menganalisa data berdasarkan nama penulis, judul, tujuan, metode penelitian dan hasil yaitu pengelompokkan data-data penting pada artikel. Adapun hasil ekstrraksi data dapat dilihat pada table 2 .

Tabel 2. Sintesis/Ekstraksi Data Hasil Penelitian

\begin{tabular}{lll}
\hline Artikel 1 & & \\
\hline Info Umum & Judul Artikel & Pengaruh Senam Kaki Diabetes Pada Pasien DM Tipe II Terhadap Nilai Ankle Brachial \\
& Nama Penulis & Index di Wilayah Kerja Puskesmas Pal Tiga Kota Pontianak \\
& Tempat Penelitian & Wilayah Kerja Puskesmas Pal Tiga Kota Pontianak \\
& Info Jurnal & Jurnal ProNers-UNTAN \\
& Tahun Publikasi & 2019 \\
Info Khusus & Jumlah Sampel & 40 respoden (20 kelompok perlakuan, 20 kelompok eksperimental) \\
& Metode Penelitian & Quasy experimental; one group pre-post test with control design \\
& Hasil & Pada kelompok perlakuan, mengalami peningkatan mean dan pada kelompok kontrol \\
& & mengalami penuruanan mean, peneliti berasumsi bahwa terdapat aktivitas fisik responden \\
& & yang mempengaruhu dari nilai ABI sesaat sebelum dilakukan pemeriksaan ABI, juga \\
& & dipengaruhi oleh kolesterol yang dimana peneliti tidak melakukan pengontrolan pada \\
& & semua responden. Intervensi senam kaki diabetes berpengaruh dalam meningkatkan \\
& & sirkulasi darah ke kaki \\
\hline Artikel 2 & & \\
\hline Info Umum & Judul Artikel & Pengaruh Senam Kaki Diabetik Terhadap Ankle Brachial Index (ABI) Pada Pasien \\
& & Diabetes Melitus Tipe II DI Puskesmas II Denpasar Selatan \\
& Nama Penulis & (I Made Lasia, I Gusti Ayu Ratih Agustini, 2020) \\
& Tempat Penelitian & Puskesmas II Denpasar Selatan \\
& Info Jurnal & Jurnal Keperawatan Terapan \\
& Tahun Publikasi & 2020 \\
Jumlah Sampel & 46 responden (23 kelompok perlakuan, 23 kelompok kontrol) \\
& Metode Penelitian & Quasy experimental; one group pre-post test with control design
\end{tabular}


Hasil

\begin{abstract}
Hasil analisis perbedaan beda nilai ABI
pada kelompok perlakuan dan kontrol didapatkan nilai $\mathrm{p}$ value pada kelompok perlakuan adalah $0.000(\mathrm{p}<0,05)$ yang menunjukkan Ho ditolak sedangkan $\mathrm{p}$-value pada kelompok kontrol adalah 0,058 ( $p>0,05)$ yang menunjukkan Ho gagal ditolak. Ini menunjukan bahwa ada perbedaan rata-rata $\mathrm{ABI}$ yang signifikan antara kelompok kontrol dan perlakuan serta ada pengaruh senam kaki diabetik terhadap ABI pada pasien diabetes melitus tipe II pada kelompok perlakuan. Latihan fisik merupakan salah satu prinsip dalam penatalaksanaan diabetes melitus. Kegiatan fisik sehari-hari dan latihan fisik teratur (3-5 kali seminggu selama 30 menit) merupakan salah satu pilar dalam penataksanaan diabetes mellitus disamping edukasi, diet dan obat-obatan (OAD dan insulin). Apabila kedua kelompok hasilnya dibandingkan maka terdapat hasil yang signifikan sehingga pemberian senam kaki diabetik sebanyak empat kali seminggu selama satu bulan, memberikan manfaat yang baik dalam meningkatkan tekanan darah di kaki.
\end{abstract}

\section{Pembahasan \\ Nilai pre test ankle brachial index sebelum diberikan senam kaki diabetik pada kelompok perlakuan dan kelompok kontrol}

Pada kedua artikel akan diharapkan dapat menunjukkan nilai pre test ankle brachial index sebelum diberikan senam kaki diabetik pada kelompok perlakuan dan kelompok kontrol.

Pada artikel pertama, instrument yang digunakan adalah lembar observasi. Responden diperiksa terlebih dahulu sehingga hasil ankle brachial index pada kelompok perlakuan pada kaki kanan dengan hasil ukur ABI gangguan ringan sebanyak 2 responden (10\%) dan gangguan sedang sebanyak 18 responden (20\%) sedangkan pada kaki kiri dengan hasil ukur ABI gangguan ringan sebanyak 3 responden (15\%) dan gangguan sedang sebanyak 17 responden (85\%). Sedangkan pada kelompok kontrol pada kaki kanan dengan hasil ukur ABI gangguan ringan sebanyak 1 responden (5\%) dan gangguan sedang sebanyak 19 responden $(95 \%)$, sementara pada kaki kiri dengan hasil ukur ABI gangguan ringan sebanyak 2 responden (10\%) dan gangguan sedang sebanyak 18 responden (90\%).(Hendri Wahyudi, Suriadi, 2019) Hal yang sama juga dilakukan oleh (I Made Lasia, I Gusti Ayu Ratih Agustini, 2020) dimana instrument yang digunakan yaitu doppler vascular dan aneroid sphygmomanometer untuk mengukur nilai ABI serta lembar observasi. Interpretasi nilai pre test $\mathrm{ABI}$ pada kelompok perlakuan didapatkan sebagian besar memiliki nilai ABI 0,70-0,90 (PAD ringan) dengan nilai rata-rata (mean) 0,88 , nilai $\mathrm{SD}$ sebesar 0,81, nilai minimum sebesar 0,76, dan nilai maksimum sebesar 1,00. Sementara interpretasi nilai pre test ABI pada kelompok kontrol didapatkan sebagian besar memiliki nilai ABI $0,70-0,90$ (PAD ringan) dengan nilai rata-rata (mean) 0,91 , nilai SD sebesar 0,11 , nilai minimal sebesar 0,76 , dan nilai maksimal sebesar 1,16 .

Hasil ukur ABI responden rata-rata mengalami obstruksi baik pada kelompok perlakuan maupun kelompok kontrol.Ini menunjukkan adanya masalah sirkulasi kaki pada kedua kelompok tersebut.Hal ini disebabkan karena adanya peningkatan viskositas darah akibat hiperglikemia yang dialami oleh responden baik pada kelompok maupun kelompok kontrol (Ivo Tomy Pompang'k Toton, 2016)

Sebelum diberikan suatu intervensi, akan dilakukan terlebih dahulu pengukuran nilai ankle brachial index menggunakan vascular dopper kemudian dicatat di lembar observasi. Hasil yang diperoleh pada pengukuran nilai ABI sebelum diberikan terapi senam kaki diabetik yaitu sebagian besar tergolong berat atau berada pada rentang nilai $>0,40$ dengan jumlah responden sebanyak 4 orang (40\%) (Girsang \& Sitorus, 2020)

Penyandang diabetes mellitus lebih banyak ditemukan pada usia dewasa yang berumur 51-60 tahun yang disebabkan karena seiring dengan proses penuaan sehingga terjadi penurunan fungsi sel atau organ tubuh seperti sel $\beta$ pancreas yang berfungsi memproduksi insulin sehingga dapat menyebabkan gangguan pada produksi insulin yang berdampak pada intoleransi glukosa (Sumarauw, 2017)

Salah satu test non intensif yang cukup sederhana untuk mengukur rasio tekanan darah sistolik kaki (ankle) dengan tekanan darah sistolik (brachial) yaitu dengan menggunakan Ankle Brachial Index (ABI). Sphygmomanometer dan stethoscope merupakan alat yang digunakan untuk mengukur tekanan darah sistolik.Pemeriksaan ABI ini dilakukan untuk mendeteksi adanya insufisiensi arteri yang menunjukkan kemungkinan adanya penyakit arteri perifer/ peripheral arterial disease (PAD) pada kaki.Selain itu, dapat juga digunakan untuk melihat hasil suatu intervensi (pengobatan, program senam, angioplasty atau pembedahan) (Zukhri, 2015)

Pasien diabetes mellitus tipe II memiliki risiko yang lebih tinggi untuk mengalami PAD yang ditandai dengan penuurunan nilai ABI.Kesemutan khususnya pada daerah kaki sering dalami oleh pasien DM tipe II yang merupakan manifestasi akibat dari sirkulasi darah yang tidak lancar.Pasien DM tipe II yang memiliki nilai ABI yang rendah sering tidak menyadari bahwa telah terjadi penyumbatan pada pembuluh darah kakinya karena PAD kadang tidak bergejala sehingga sangat penting dilakukan pemeriksaan ABI untuk mengetahui sirkulasi darah pada kaki (Ni Putu Erna Libya, 2018). 
Berdasarkan uraian di atas, untuk mengetahui keadekuatan sirkulasi pembuluh darah perifer ke arah tungkai maka dilakukan pemeriksaan Ankle Brachial Index (ABI). Melalui pemeriksaan ini akan diidentifikasi ada atau tidaknya gangguan pada sirkulasi perifer pasien, sehingga dapat dijadikan sebagai indikator tingkat keparahan penyakit pembuluh darah arteri perifer. Selain itu, pemeriksaan ini dianjurkan pada pasien diabetes mellitus tipe II terutama yang memiliki faktor resiko seperti merokok, obesitas, dan tingginya kadar trigliserida dalam darah.

Nilai post test ankle brachial index pasien penderita DM tipe II setelah diberikan senam kaki diabetik pada kelompok perlakuan dan kelompok kontrol

Pada kedua artikel diharapkan dapat menunjukkan nilai post test ankle brachial index setelah diberikan senam kaki diabetik pada kelompok perlakuan dan kelompok kontrol yang tidak diberikan senam kaki diabetik.

Pada artikel pertama, setelah responden diberikan senam kaki diabetik, maka hasil ankle brachial index pada kelompok perlakuan pada kaki kanan dengan hasil ukur ABI gangguan ringan sebanyak 6 responden $(30 \%)$ dan gangguan sedang sebanyak 14 responden (70\%) sementara pada kaki kiri didapatkan hasil ukur ABI gangguan ringan sebanyak 9 responden $(45 \%)$ dan gangguan sedang sebanyak 11 responden (55\%). Terjadi peningkatan jumlah responden dari gangguan sedang yang mengalami peningkatan nilai ABI menjadi gangguan ringan.Senam kaki dapat meningkatkan nilai ankle brachial index pada pasien diabetes mellitus. Sedangkan pada kelompok kontrol pada kaki kanan dengan hasil ukur ABI gangguan sedang sebanyak 20 responden $(100 \%)$ dan pada kaki kiri dengan hasil ukur ABI gangguan sedang sebanyak 20 responden (100\%). Terjadi perubahan nilai post test ankle brachial index pada responden walaupun kelompok kontrol ini tidak mendapatkan intervensi senam kaki diabetik (Wahyudi, $\mathrm{dkk}, 2019$ ).

Hal yang sama juga dilakukan oleh (I Made Lasia, I Gusti Ayu Ratih Agustini, 2020) setelah diberikan senam kaki diabetik maka nilai ABI pada kelompok perlakuan rata-rata 1,02 termasuk kategori normal. Hal ini menunjukkan bahwa setelah diberikan senam kaki diabetik sebanyak tiga kali seminggu selama empat minggu telah terjadi peningkatan nilai $\mathrm{ABI}$ sebesar 0,14 dari 0,88 sebelum senam kaki diabetik menjadi 1,02 setelah senam kaki diabetik sehingga ABI pada kelompok perlakuan masuk dalam kategori normal. Sedangkan pada kelompok kontrol memiliki nilai ratarata post test $\mathrm{ABI}$ pada pasien DM tipe II adalah 0,91 termasuk kategori normal. Nilai rata-rata $\mathrm{ABI}$ setelah pelaksanaan senam kaki diabetik adalah 0,94 , nilai minimum $\mathrm{ABI}$ adalah 0,76 , nilai maksimum adalah 1,2 , standar deviasi adalah 0,12. Ini artinya bahwa pada kelompok kontrol tidak mengalami perubahan yang signifikan terhadap nilai ABI walau tidak mendapatkan intervensi senam kaki diabetik.

Saat kelompok perlakuan diberikan intervensi senam kaki maka akan terjadi peningkatan jumlah responden dengan hasil ukur ABI normal. Setelah melakukan senam kaki terjadi peningkatan kebutuhan bahan bakar tubuh oleh otot yang aktif. Bukan itu saja, akan terjadi pergerakan tungkai yang mengakibatkan otot-otot tungkai menegang dan menekan vena di sekitar otot-otot tersebut (Ivo Tomy Pompang'k Toton, 2016)

Pasien DM tipe II di Puskesmas Bergas menunjukkan rata-rata nilai $\mathrm{ABI}$ sesudah dilakukan senam kaki pada nilai 0,97 atau pada klasifikasi ABI borderline. Aliran darah yang dipompakan jantung ke seluruh tubuh salah satunya kaki, dipengaruhi oleh tiga faktor yaitu kekentalan darah, panjang pembuluh darah dan diameter pembuluh darah. Senam kaki diabetik merupakan salah satu senam aerobic yang variasi gerakan-gerakannya pada daerah kaki sehingga setiap tahapan gerakan harus dilakukan (Tut Wuri Prihatin, 2019)

Senam diabetes yang rutin akan meningkatkan vaskularisasi pada penderita diabetes. Senam ini membantu perbaiki sirkuasi darah yang terganggu, melatih sendi agar tetap lentur, mencegah komplikasi diabetes pada organ seperti pada mata, otak, jantung, dan ginjal. Sehingga dengan adanya latihan fisik ini akan merangsang pembuluh darah untuk berdilatasi melalui gerakan kaki yang akan mengurangi gangguan perfusi jaringan (Novita Anggraini, 2020)

Berdasarkan uraian di atas, pasien diabetes mellitus setelah dilakukan senam kaki, akan menghasilkan perubahan pada nilai $A B I$. Ini menunjukkan bahwa senam kaki sangat baik dilakukan oleh pasien diabetes mellitus tipe sehingga dapat meningkatkan nilai ABI pada pasien diabetes mellitus.

\section{Pengaruh senam kaki diabetik terhadap nilai ankle brachial index (ABI) pada pasien DM tipe II}

Pada kedua artikel diharapkan dapat menunjukkan pengaruh senam kaki diabeteik terhadap nilai ankle brachial index (ABI) pada pasien DM tipe II.

Dari artikel pertama, menunjukkan bahwa pada kelompok perlakuan mengalami peningkatan mean dan pada kelompok kontrol mengalami penurunan mean. Aktifitas fisik responden mempengaruhi dari nilai $\mathrm{ABI}$ sesaat sebelum dilakukan pemeriksaan $\mathrm{ABI}$, dan juga dipengaruhi oleh kolesterol yang mana peneliti tidak melakukan pengontrolan pada semua responden.Sehingga dapat disimpulkan bahwa intervensi senam kaki diabetes berpengaruh dalam meningkatkan sirkulasi darah ke kaki (Hendri Wahyudi, Suriadi, 2019).Hal yang sama juga dijelaskan pada artikel kedua. Bila dibandingkan hasil nilai ABI untuk kedua kelompok maka terdapat hasil yang signifikan.Sehingga senam kaki diabetik dapat diberikan sebanyak empat kali seminggu selama satu bulan, memberikan manfaat 
yangbaik dalam meningkatkan tekanan darah di kaki (Lasia, dkk, 2020).

Hal yang sama juga diungkapkan Kaimuddin \& Selamat (2019) bahwa ada pengaruh antara penerapan senam diabetes dalam perubahan nilai $\mathrm{ABI}$ penderita diabetes mellitus. Penerapan senam diabetes sebagai salah satu aktifitas penderita dalam penurunan kadar gula darah pasien diabetes mellitus. Sehingga program senam diabetes yang telah dilakukan, lebih baik lagi jika frekuensi senam menjadi $3 \mathrm{kali} /$ minggu sehingga memberikan dampak yang baik bagi penderita diabetes mellitus.

Nilai ABI pada pasien diabetes mellitus di wilayah kerja Puskesmas Banjar II mengalami peningkatan setelah diberikan senam kaki, meskipun terdapat kesamaan kategori nilai ABI pada saat pretest dan posttest.Namun terdapat perbedaan jumlah yang signifikan sehingga dikatakan berhasil karena terapi yang diberikan telah sesuai dengan standar prosedur operasional senam kaki dan terdapat kerjasama antara penderita DM tipe 2 dan pemberi terapi pada saat diberikannya intervensi (Febrinasari et al., 2020)

Senam kaki diabetes yang dilakukan rutin dan teratur oleh pasien diabetes mellitus sangat berdampak bagi nilai ankle brachial index yang terjadi pada setiap individu.Senam kaki ini dapat dilakukan dengan mudah oleh pasien diabetes mellitus karena hanya menggunakan koran dan kursi, dapat dilakukan kapan saja dan dimana saja tanpa mengganggu aktivitas yang lainnya, tidak memerlukan biaya yang banyak, tidak menyebabkan kelelahan atau membuang energi yang banyak, dan memiliki manfaat yang banyak bagi penderita diabetes mellitus (Mangiwa et al., 2017)

Senam kaki diabetes merupakan salah satu olahraga praktik yang dapat dimanfaatkan bagi pasien diabetes mellitus tipe dua untuk memperbaiki sirkulasi darah yang terganggu, melatih sendi supaya tetap lentur, mencegah komplikasi diabetes pada organ seperti pada mata, otak, jantung, dan ginjal. Apabila dilakukan senam kaki ini akan merangsang pembuluh darah untuk berdilatasi melalui gerakan-gerakan kaki sehingga mengurangi gangguan perfusi jaringan (Anggraini 2020).

Berdasarkan uraian diatas, senam kaki diabetes ini sangat efektif dilakukan bagi penderita diabetes mellitus tipe 2.Senam kaki ini memberikan manfaat yang besar bagi penderita tersebut, sehingga dapat mencegah komplikasi kaki diabetes seperti gangguan pembuluh darah, luka terbuka yang sulit sembuh serta masa kaki lainnya.Penderita diabetes mellitus tipe dua dapat melakukan senam ini dengan sangat mudah dan praktis sebab dapat dilakukan dimanasaja dan kapan saja oleh penderita tersebut.

\section{SIMPULAN}

Berdasarkan hasil tinjauan sistematis yang telah dilakukan tentang senam kaki terhadap nilai ancle brachial index pada pasien diabetes mellitus tipe II maka disimpulkan bahwa senam kaki ini berpengaruh dalam meningkatkan nilai ABI terhadap pasien diabetes mellitus.Selain itu senam ini sangat efektif dilakukan karena dapat dilakukan dengan mudah oleh pasien. Jika senam ini dilakukan secara berulang maka akan memberikan perubahan yang lebih baik pada rentang gerak sendinya.

\section{DAFTAR PUSTAKA}

Amarican Diabetes Association. (2020). 2 . Classi fi cation and Diagnosis of Diabetes: Standards of Medical Care in Diabetes d 2020, 43(January), 14-31. https://doi.org/10.2337/dc20-S002

Febrinasari, R. P., Maret, U. S., Sholikah, T. A., Maret, U. S., Pakha, D. N., Maret, U. S., ... Maret, U. S. (2020). Buku Saku Diabetes Melitus Untuk Awam. Buku Saku, (November), 21.

Girsang, R., \& Sitorus, F. E. (2020). Pengaruh Senam Kaki Diabetik Terhadap Ankle Brachial. Jurnal Penelitian Keperawatan Medik, 2(2). Retrieved from

http://ejournal.delihusada.ac.id/index.php/JPKM/a rticle/view/201

Hendri Wahyudi, Suriadi, H. (2019). Pengaruh Senam Kaki Diabetes Pada DM Tipe 2 Terhadap Nilai Ankle Branchial Indexs di Wilayah Kerja Puskesmas Pal Tiga Kota Pontianak.

I Made Lasia, I Gusti Ayu Ratih Agustini, N. K. P. (2020). PENGARUH SENAM KAKI DIABETIK TERHADAP ANKLE BRACHIAL INDEX ( ABI ) PADA PASIEN DIABETES MELLITUS TIPE II DI PUSKESMAS II DENPASAR SELATAN, 6(1), 43-55.

INFODATIN RI, P. D. dan I. K. K. (2018). HARI DIABETES SEDUNIA TAHUN 2018.

Ivo Tomy Pompang'k Toton. (2016). Ankle Brachial Index Pada Pasien Diabetes Melitus Di Wilayah Kerja Puskesmas Purnama Ivo Tomy Pompang ' K Toton Nim I31112064 Program Studi Ilmu Keperawatan Ankle Brachial Index Pada Pasien Diabetes Melitus.

Kaimuddin, K., \& Selamat, S. (2019). Pengaruh Senam Diabetes Terhadap Nilai Ankle Brachial Index (Abi) Penderita Diabetes Mellitus. Jurnal Bahana Kesehatan Masyarakat (Bahana of Journal Public Health), 3(2), 102-107. https://doi.org/10.35910/jbkm.v3i2.224

Lung, C., Wu, F., Liao, F., Pu, F., Fan, Y., \& Jan, Y. (2020). Emerging technologies for the prevention and management of diabetic foot ulcers. Journal of Tissue Viability, (March), 0-1. https://doi.org/10.1016/j.jtv.2020.03.003

Mangiwa, I., Katuuk, M., \& Sumarauw, L. (2017). Pengaruh Senam Kaki Diabetes Terhadap Nilai Ankle Brachial Index Pada Pasien Diabetes Melitus Tipe Ii Di Rumah Sakit Pacaran Kasih 
Yofa Anggriani Utama dan Sutrisari Sabrina Nainggolan, Pengaruh Senam Kaki terhadap Nilai Ankle Brachial Index Pada

Gmim Manado. Jurnal Keperawatan UNSRAT, 5(1), 105018.

Matos, M., Mendes, R., Silva, A. B., \& Sousa, N. (2018). Physical activity and exercise on diabetic foot related outcomes: a systematic review. Diabetes Research and Clinical Practice. https://doi.org/10.1016/j.diabres.2018.02.020

Mcdermott, M. M. (2017). Exercise training for intermittent claudication. Journal of Vascular Surgery, 1-9. https://doi.org/10.1016/j.jvs.2017.05.111

Megawati, S. W., Utami, R., \& Jundiah, R. S. (2020). Senam Kaki Diabetes Pada Penderita Diabetes Melitus Tipe 2 Untuk Meningkatkan Nilai Ankle Brachial Indexs, 3(2).

Ni Putu Erna Libya. (2018). Pengaruh Senam Kaki Diabetik Terhadap Ankle Brachial Index (Abi) Pada Pasien Diabetes Melitus Tipe Ii Di Upt Kesmas Gianyar I.

Novita Anggraini. (2020). Literatur Riview Pengaruh Senam Kaki Terhadap Ankle Branhial Index Pada Pasien Diabetes Melitus Tipe II. Journal of Chemical Information and Modeling, 21(1), 1-9. Retrieved from https://doi.org/10.1016/j.tmaid.2020.101607\%0Ah ttps://doi.org/10.1016/j.ijsu.2020.02.034\%0Ahttps ://onlinelibrary.wiley.com/doi/abs/10.1111/cjag.12 228\%0Ahttps://doi.org/10.1016/j.ssci.2020.10477 3\%0Ahttps://doi.org/10.1016/j.jinf.2020.04.011\% 0Ahttps://doi.o

Simarmata, P. C., Sri, A., Purba, G., \& Lestari, A. (2021). PENGARUH SENAM KAKI TERHADAP NILAI ANKLE BRACHIAL INDEKS PADA PASIEN DIABETES MELITUS DI RUMAH SAKIT GRANDMED LUBUK PAKAM, 3(2). https://doi.org/10.35451/jkf.v3i2.674

Sumarauw, I. M. M. E. K. L. (2017). PENGARUH SENAM KAKI DIABETES TERHADAP NILAI ANKLE BRACHIAL INDEX PADA PASIEN DIABETES MELITUS, 5.

Tut Wuri Prihatin, R. D. M. (2019). Senam Kaki Diabetes Berpengaruh Terhadap Nilai Ankle Brachial Index (ABI) Pada Pasien Diabetes Melitus Tipe II, 9(46), 571-576.

Zukhri, S. (2015). Pengaruh senam kaki terhadap, 0. Retrieved from http://ejournal.stikesmukla.ac.id/index.php/motor/ article/download/310/298. 